Original Article

\title{
EXTRACELLULAR POLYMERIC SUBSTANCE (EPS) FROM KOCURIA SP. BRI 36: A KEY COMPONENT IN HEAVY METAL RESISTANCE
}

\author{
ANURADHA MULIK, RAMA BHADEKAR \\ Department of Microbial Biotechnology, Rajiv Gandhi Institute of IT and Biotechnology, Bharati Vidyapeeth Deemed University, Pune \\ 411046, India \\ Email: neeta.bhadekar@gmail.com \\ Received: 07 Nov 2017 Revised and Accepted: 28 Mar 2018
}

ABSTRACT

Objective: Evaluation of Extracellular Polymeric Substance (EPS) induced heavy metal tolerance in Kocuria sp. BRI 36.

Methods: Initially, the effect of different concentrations of glucose (1-10\%) on EPS production by BRI 36 was examined. At optimum glucose concentrations, EPS levels were measured by varying heavy metal concentrations (10-50 ppm) of $\mathrm{Pb}^{2+}, \mathrm{Cd}^{2+} \mathrm{and}^{3} \mathrm{Cr}^{3+}$. Maximum tolerable concentration (MTC) and survival percentage of BRI 36 were determined under conditions that support EPS synthesis. Comparative analysis of extracted crude EPS was performed by Fourier Transform Infrared Spectroscopy (FTIR) to establish functional groups involved in the metal interaction.

Results: Kocuriasp. BRI 36 produced maximum EPS (1g/l) at 5\% glucose. Increase in EPS production up to 89\% (considering 1g/l as 100\%) with an increase in concentrations of heavy metals up to $40 \mathrm{ppm}$. MTC levels of BRI 36 for heavy metals increased up to 700 ppm when it was cultivated in presence of $5 \%$ glucose indicating a major role of surface polymer in metal adsorption. The function of EPS as a protective cover was also evident from an increase in survival percentage of BRI 36 up to 39.4 at MTC. Comparative analysis of extracted crude EPS by FTIR revealed the involvement of $\mathrm{O}-\mathrm{H}, \mathrm{C}=\mathrm{O}$, and $\mathrm{C}-\mathrm{O}-\mathrm{C}$ groups in metal adsorption

Conclusion: Antarctic oceanic isolate Kocuria sp. BRI 36 has an ability to produced EPS under stress conditions of heavy metals. Simultaneously, its MTC values increased due to increase in EPS levels. These observations suggest the possibility to develop gentle, environmentally safe and costeffective method for heavy metal removal.

Keywords: Exopolysaccharides, Fourier Transform Infrared Spectroscopy (FTIR), heavy metals, Maximum Tolerable Concentration (MTC)

(C) 2018 The Authors. Published by Innovare Academic Sciences Pvt Ltd. This is an open access article under the CC BY license (http://creativecommons.org/licenses/by/4.0/) DOI: http://dx.doi.org/10.22159/ijpps.2018v10i5.23535

\section{INTRODUCTION}

Many bacteria produce biopolymers with varied chemical properties through the utilization of simple to complex substrates. They could either be intracellular or extracellular. The extracellular polymeric substances (EPS), also known as exopolysaccharides, have a high molecular weight and consist mainly of carbohydrates. However, the intracellular biopolymers are few and have very limited use [1]. EPS may be grouped into four major classes; polysaccharides, inorganic polyanhydrides (such as polyphosphates), polyesters, and polyamides [2].

Most marine bacteria can produce EPS, which occur in two forms viz. capsular polysaccharides in which the polymers are covalently bound to the cell surface; and slime polysaccharides that either remain attached (loosely bound) to the cell surface or are released into the environment $[3,4]$. EPS produced by marine bacteria are thought to play a key role in the protection against the marine environment characterized by extreme physicochemical conditions such as low or high temperature, high pressure, low nutrient concentration, high salinity, and heavy metal presence [5]. Occurrence of heavy metals in soil and water are found to be important micronutrients, provided that the levels are in a limit [6, 7] or else they contaminate natural resources which in turn has an adverse effect on the ecosystem [8,9]. BRI isolates from Antarctic oceanic region have an ability to grow under extreme environmental conditions [10]. Among them red-orange pigment producing Kocuriasp. BRI 36 was observed to tolerate and accumulate heavy metals [11]. The response of BRI 36 to different heavy metals at different concentrations in terms of amount and color of pigment produced might prove useful in the detection of heavy metal contamination [12]. Our recent studies showed the possible role of chromosomal genetic elements in heavy metal tolerance of BRI 36 [13].
The isolate under study was also found to produce EPS at high sugar concentration. Interestingly, heavy metal tolerance of BRI 36 in terms of maximum tolerable concentration (MTC) was found to increase considerably with an increase in EPS produced by the isolate. Role of EPS in metal resistance has been previously documented by various researchers [14-17]. These observations prompted us to undertake studies on EPS production, and its effect on heavy metal tolerance of Kocuria sp. BRI 36.

\section{MATERIALS AND METHODS}

\section{Chemicals and reagents}

All the media components were purchased from HiMedia Laboratories Pvt. Ltd. (Mumbai, India). The stock solutions of cadmium, lead and chromium at the concentrations of $1000 \mathrm{ppm}$ each were purchased from Sigma-Aldrich. All chemicals and reagents used were of analytical grade.

\section{Analysis of EPS}

Kocuriasp. BRI 36 was cultivated on Mineral Salt Medium (MSM) at $30 \pm 2{ }^{\circ} \mathrm{C}$ for $48 \mathrm{~h}$ with $10 \%$ inoculum. The isolate was then grown in MSM containing $5 \%$ glucose at $30 \pm 2{ }^{\circ} \mathrm{C}$ for $48 \mathrm{~h}$. The occurrence of slimy colonies at the end of incubation period indicated EPS production by BRI 36. The isolate was then grown in MSM containing $5 \%$ glucose at $30 \pm 2{ }^{\circ} \mathrm{C}$ for $48 \mathrm{~h}$ with shaking at $120 \mathrm{rpm}$. The contents were centrifuged (7826 $\mathrm{xg}$ for $20 \mathrm{~min}$ ) and the culture cell-free broth was used to estimate EPS as carbohydrates following phenol-sulphuric acid method [18].

\section{EPS production at different sugar concentrations}

The production of Extracellular Polymeric Substance (EPS) was studied by growing the isolate at different concentrations of glucose $(1-10 \%)$ and EPS as carbohydrates were estimated as mentioned above. 


\section{Effect of heavy metals}

Kocuriasp. BRI 36 was cultivated in MSM amended with 5\% glucose. The effect of $\mathrm{Pb}^{2+}, \mathrm{Cd}^{2+}$ and $\mathrm{Cr}^{3+}$ at different concentrations (10 ppm$50 \mathrm{ppm}$ ) was examined individually on EPS production, The EPS estimation was carried out as mentioned above.

\section{Maximum tolerable concentration (MTC)}

MTC of Kocuria sp. BRI 36 was determined by growing the isolate in MSM supplemented with $5 \%$ glucose. $\mathrm{Cd} 2+, \mathrm{Pb} 2+$ and $\mathrm{Cr} 3+$ were added individually at concentrations ranging from $200-700 \mathrm{ppm}$. The samples were incubated for $48 \mathrm{~h}$ at $30 \pm 2{ }^{\circ} \mathrm{C}$ with shaking at $120 \mathrm{rpm}$.

\section{Extraction of EPS}

Kocuriasp. BRI 36 was grown in Mineral Salt Medium (MSM) with $5 \%$ glucose at $30 \pm 2{ }^{\circ} \mathrm{C}$ for $48 \mathrm{~h}$ with shaking at $120 \mathrm{rpm}$ and biomass was separated by centrifugation at $7826 \mathrm{xg}$ for $15 \mathrm{~min}$. The cell-free broth was then treated with $20 \%$ trichloroacetic acid (TCA) to precipitate protein fraction. Precipitated proteins were separated by centrifugation at $7826 \mathrm{xg}$ for $15 \mathrm{~min}$. The clear cell-free broth was used for EPS precipitation by adding two volumes of chilled ethanol. EPS obtained by filtration was calculated gravimetrically on the dry weight basis [19]. It was used as crude EPS for further experiments.

\section{Fourier transform infrared spectroscopy (FTIR)}

One milligram of crude dry EPS was directly used for FTIR (Brucker, tensor 37) analysis. The conditions used were 16 scans at a resolution of $4 \mathrm{~cm}^{-1}$ measured between $400 \mathrm{~cm}^{-1}$ and $4000 \mathrm{~cm}^{-1}$.

\section{RESULTS AND DISCUSSION}

Kocuriasp. BRI 36 was found to produce EPS when grown in presence of $5 \%$ glucose. Increase in glucose concentration up to 10 $\%$ resulted in increase in total carbohydrate in cell-free broth with a maximum yield of $1 \mathrm{mg} / \mathrm{ml}$ at $5 \%$ glucose concentration (table 1).

Table 1: Effect of different glucose concentrations on EPS production

\begin{tabular}{lll}
\hline Glucose concentration (\%) & EPS production $\mathbf{\text { (mg/ml) }}$ & \% Survival \\
\hline 1 & $0.164 \pm 0.0005$ & 16.44 \\
2 & $0.250 \pm 0.0005$ & 25.06 \\
3 & $0.449 \pm 0.0005$ & 44.90 \\
4 & $0.50 \pm 0.0005$ & 50.39 \\
5 & $1.00 \pm 0.05$ & 100.00 \\
6 & $0.394 \pm 0.001$ & 39.42 \\
7 & $0.362 \pm 0.0005$ & 36.29 \\
8 & $0.339 \pm 0.0005$ & 33.94 \\
10 & $0.258 \pm 0.0005$ & 25.84 \\
\hline
\end{tabular}

${ }^{a}$ mean $\pm S D, n=3$.

In order to examine the effect of heavy metals on EPS production, the isolate was cultivated in presence of increasing concentrations of heavy metals individually along with $5 \%$ glucose. We observed an increase in carbohydrate content $(0.2$ to $89 \%$ considering $1 \mathrm{~g} / \mathrm{l}$ as
$100 \%$ yield) in cell-free broth up to $30 \mathrm{ppm}$ metal concentration for lead and chromium while, in presence of 40 ppm cadmium, maximum EPS yield was detected (table 2). Metal-induced EPS synthesis has previously reported in various microorganisms [22].

Table 2: Effect of different concentration of heavy metals on EPS production

\begin{tabular}{lll}
\hline Metal concentration (ppm) & \multicolumn{2}{l}{ EPS production byKocuria sp. BRI 36 (mg/ml) } \\
\cline { 2 - 3 } & Chromium & \multicolumn{1}{l}{ Lead } \\
\hline 10 & $1.071 \pm 0.0005$ & $1.27 \pm 0.005$ \\
20 & $1.151 \pm 0.001$ & $1.78 \pm 0.005$ \\
30 & $1.300 \pm 0.02$ & $1.89 \pm 0.005$ \\
40 & $1.071 \pm 0.0005$ & $1.23 \pm 0.005$ \\
50 & $1.063 \pm 0.0005$ & $1.20 \pm 0.005$ \\
\hline
\end{tabular}

mean $\pm \mathrm{SD}, \mathrm{n}=3$.

Kocuriasp. BRI 36 possesses the ability to tolerate high concentrations of heavy metals in the range of 300 to $600 \mathrm{ppm}$ isolate demonstrated MTC of 500 ppm for each of $\mathrm{Cd}^{2+}, \mathrm{Pb}^{2+}$ and $\mathrm{Cr}^{3+}$ with survival percentage in the range of 16.1 to $29 \%$ [11]. In the present investigation, we examined the effect of an increase in the concentration of glucose on MTC of Kocuria sp. BRI 36. We observed an increase in MTC values and improved percent survival of BRI 36 (table 3). Maximum MTC of 700 ppm was noted for $\mathrm{Pb}^{2+}$ followed by $\mathrm{Cd}^{2+}(600 \mathrm{ppm})$ and $\mathrm{Cr}^{3+}(600 \mathrm{ppm})$. Interestingly, percent survival increased from 36.12 to $39.4 \%$ (table 3 ) at MTC. These observations along with an increase in EPS levels (as mentioned above) suggest a significant role of EPS in metal tolerance. Earlier many researchers discussed enhanced EPS levels in microorganisms when cultivated under stress [23-26]. Synthesis of EPS is one of the mechanisms adopted by microorganisms to protect themselves from permeation of toxic metal ions. EPS, acting as a protective shield, sequesters metal ions, thereby inhibiting their penetration. The interaction might immobilize metal ions. Thus, as suggested by Gupta and Diwan EPS production can be considered as constitutive nonspecific mechanism displayed by microorganisms in the response of heavy metals [22].

Table 3: Increase in MTC and survival rate of Kocuria sp. BRI 36 at 5\% glucose

\begin{tabular}{llll}
\hline Isolate & Metals & At 5\% glucose & \% Survival \\
\cline { 2 - 4 } & & MTC (ppm) & 36.12 \\
\hline BRI 36 & $\mathrm{Pb}^{2+}$ & 700 & 35.3 \\
& $\mathrm{Cr}^{3+}$ & 600 & 39.4 \\
\hline $\mathrm{Cd}^{2+}$ & 600 & \\
\hline
\end{tabular}


Bhadekar et al.

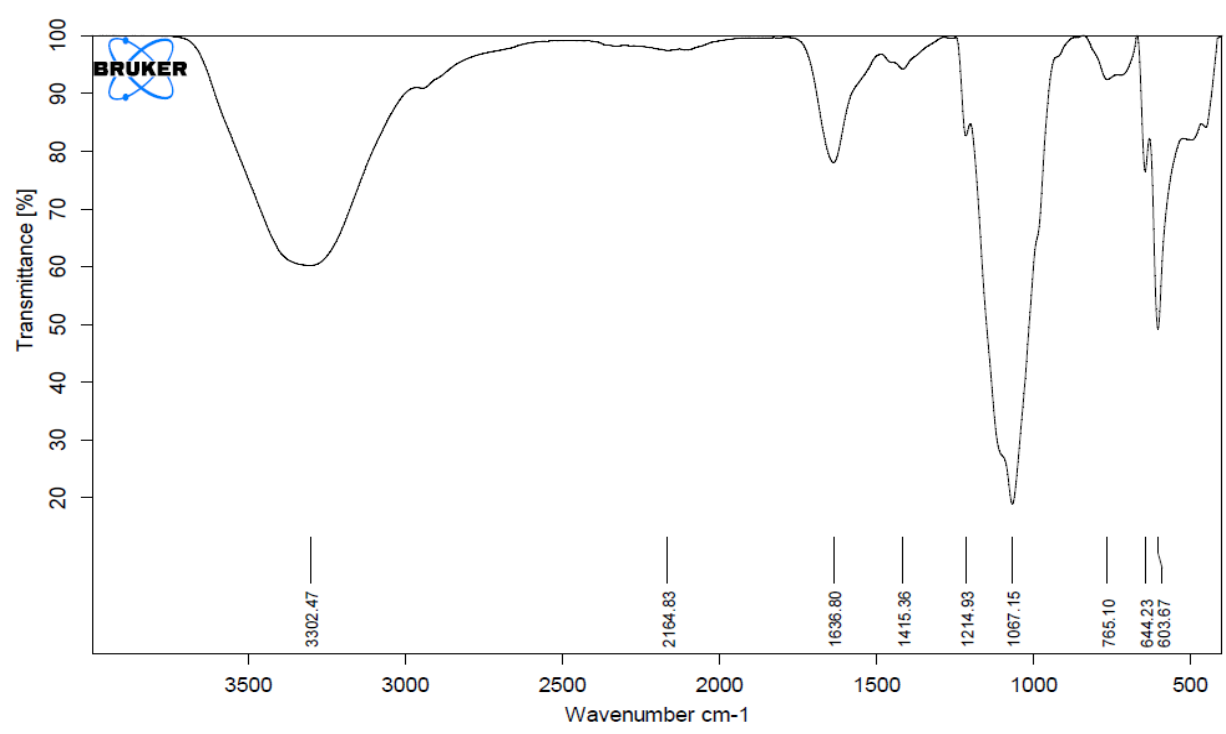

a)



b)



c) 


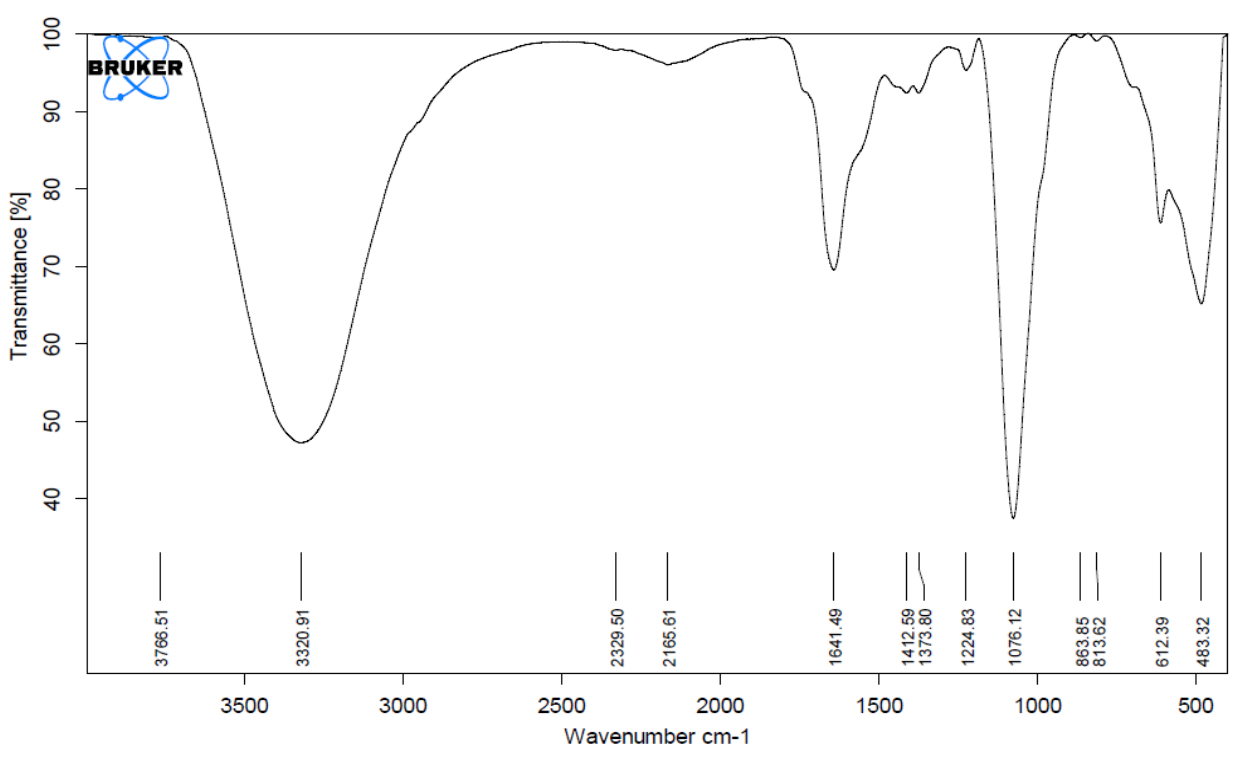

d)

Fig. 1: FTIR spectra of a) control, b) cadmium treated EPS, c) lead treated EPS and d) chromium treated EPS

Fourier Transform Infrared Spectroscopy (FTIR) analysis of crude EPS produced by Kocuria sp. BRI 36 revealed distinct stretching frequencies of chemical groups (fig. 1a). The dominant peaks were observed at $3302.47,2164.83,1636.80,1415.36,1214.14,1067.15$, $765.10,644.23$ and $603.67^{\mathrm{cm}-1}$ respectively. This is in accordance to the peak assignment of $3400-3200 \mathrm{~cm}-1(\mathrm{O}-\mathrm{H}$ or $\mathrm{H}$ bond $), 3000-$ $2800 \mathrm{~cm}-1$ (C-H bond), $1850-1600 \mathrm{~cm}-1$ (C=O bond), $1400-1370 \mathrm{~cm}-1$ (C-O bond), $1240{ }^{\mathrm{cm}-1}\left(\mathrm{C}=0\right.$ bond) and $900-1150{ }^{\mathrm{cm}-1}$ (C-O-C bond) [27]. However, analysis of EPS extracted from BRI 36 cultivated in metalcontaining media demonstrated shifts in wave numbers (fig. 1b, 1c, 1d) as compared to control (fig. 1a). Noticeable alterations were observed in $\mathrm{Pb}^{2+}$ and $\mathrm{Cd}^{2+}$ loaded EPS samples indicating metal adsorption to carboxyl groups present on EPS. Moreover, shifts observed at 1076 to $1120^{\mathrm{cm}-1}$ are due to the characteristic of uronic acid, 0-acetyl ester linkage bond [28]. Our observations are in line with the explanation specified by Zhang et al. and Guibaudet al. that, metal adsorption involves ' $O$ ' of the polymeric structure interacts with metal in adsorption process to reduce the electron cloud density of functional groups containing oxygen and causing shifts in vibration frequency and intensity $[29,30]$. Involvement of $\mathrm{O}-\mathrm{H}, \mathrm{C}=\mathrm{O}$, and $\mathrm{C}-\mathrm{O}-\mathrm{C}$ groups in heavy metal adsorption by EPS was also reported by Perez et al. [31] during their studies on Paenibacillusjamilae.

\section{CONCLUSION}

Maximum Tolerable Concentration (MTC) of Kocuria sp. BRI 36 for $\mathrm{Pb}^{2+}, \mathrm{Cd}^{2+}$ and $\mathrm{Cr}^{3+}$ increased and percent survival at MTC increased considerably when the isolate was grown in presence of glucose. This may be attributed to increased levels of an extracellular polymeric substance (EPS) observed in presence of metals. The assumption was further established by Fourier Transform Infrared Spectroscopy (FTIR) analysis of samples. The comparative studies confirmed the involvement of $\mathrm{O}-\mathrm{H}, \mathrm{C}=\mathrm{O}$, and $\mathrm{C}-\mathrm{O}-\mathrm{C}$ groups present on exopolysaccharides in metal adsorption. Therefore, use of surface polymer produced by Kocuria sp. BRI 36 might prove an effective biocontrol method by reducing the availability of heavy metals, thus reducing adverse effect caused by their uptake and/or accumulation.

\section{ACKNOWLEDGEMENT}

We gratefully acknowledge financial support from Bharati Vidyapeeth Deemed University, Pune to undertake this work.

\section{AUTHORS CONTRIBUTIONS}

All the experimental part of the work was completed by Anuradha Mulik. Rama Bhadekar contributed through planning of the work, result analysis, a compilation of the work and manuscript writing.

\section{CONFLICTS OF INTERESTS}

No conflict of interest was reported by the authors

\section{REFERENCES}

1. Nwodo UU, Green E, Okoh AI. Bacterial exopolysaccharides: functionality and prospects. Int J Mol Sci 2012;13 Suppl 11:14002-15.

2. Cerning J. Production of exopolysaccharides by lactic acid bacteria and dairy Propionibacteria. Le Lait INRA Editions 1995; 75 Suppl 45:463-72.

3. Heissenberger A, Leppard GG, Herndl GJ. The relationship between the intracellular integrity and the morphology of the capsular envelope in attached and free-living marine bacteria. Appl Environ Microbiol 1996;62:4521-8.

4. Manivasagan P, Kim SK. Extracellular polysaccharides produced by marine bacteria. Adv Food Nutr Res 2014;72:79-94.

5. Poli A, Anzelmo G, Nicolaus B. Bacterial exopolysaccharides from extreme marine habitats: production, characterization and biological activities. Mar Drugs 2010;8:1779-802.

6. Mohd Fuat a Razak, Kofi e Aidoo. Toxicity studies of EurycomaLongifolia (jack)based remedial products. Asian J Pharm Clin Res 2011;4:23-7.

7. Hussain BI, Ramzan M, Riaz M, Bokhari TH, Rehman G, Munir S. Determination of trace heavy metals in different varieties of vegetables and fruits available in the local market of shorkotpakistan. Int J Curr Pharma Res 2013;5:101-5.

8. Sundhar, Vijayalakshmi, Adithya G, Deepanraj A, Utham G, Ranjitha J. Multi-elemental analysis of extract from pongamiapinnata. Asian J Pharm Clin Res 2015;8:88-91.

9. Shah B, Pandya D, Patel H, Ayalew A, Shah A. Zeoliticcomposites from agricultural detritus for pollution remedy: a review. J Crit Rev 2016;3:41-9.

10. Pote S, Chaudhary Y, Upadhayay S, Tale V, Walujkar S, Bhadekar R. Identification and biotechnological potential of psychrotrophic marine isolates. Eurasia J Biosci 2014; Suppl 8:51-60.

11. Mulik AR, Bhadekar RK. Heavy metal removal by bacterial isolates from the antarctic oceanic region. Int J Pharm Bio Sci 2017; Suppl 8:535-43.

12. Mulik AR, Bhadekar RK. Production and partial characterization of pigments produced by Kocuriasp BRI 36: influence of heavy metals. Int J Pharm Pharm Sci 2017;9 Suppl 10:137-45.

13. Mulik AR, Bhadekar RK. Co-relation between heavy metal resistance and antibiotic susceptibility in halotolerant bacteria 
isolated from the antarctic oceanic region. Int J Pharm Bio Sci 2017;8(4, Suppl (B):302-6.

14. Nocelli N, Bogino PC, Banchio E, Giordano W. Roles of extracellular polysaccharides and biofilm formation in heavy metal resistance of rhizobia. Materials 2016;9 Suppl 6:418

15. Gupta P, Diwan B. Bacterial exopolysaccharide mediated heavy metal removal: a review on biosynthesis, mechanism and remediation strategies. Biotechnol Reports 2017;13 Suppl:58-71.

16. Voica, Doriana MA lina. Heavy metal resistance in halophilic bacteria and archaea. FEMS Microbiol Lett 2016;363 Suppl 14:10-93.

17. Govarthanan, Muthusamy, Jaehong Shim, Loganathan Praburaman, Seol Ah Kim, Byung Taek Oh. Isolation of an exopolysaccharide-producing heavy metal-resistant halomonas Sp. MG. Arch Microbiol 2015;198:205-9.

18. Dubois M, Gilles KA, Hamilton JK, Rebers PA, Smith F. Colorimetric method for determination of sugars and related substances. Anal Chem 1956;28:350-6.

19. Deshmukh SV, Kanekar PP, Bhadekar RK, Dhar SK. Exopolysaccharide producing halophilic microorganisms from West Coast of Maharashtra, India. Int J Pharm Bio Sci 2017;8 Suppl 1:370-5.

20. Gudiña EJ, Rocha V, Teixeira JA, Rodrigues LR. Antimicrobial and antiadhesive properties of a biosurfactant isolated from Lactobacillus paracasei ssp. P aracasei A20. Lett Appl Microbiol 2010;50:419-24.

21. Heinemann C, van HylckamaVlieg JE, Janssen DB, Busscher HJ, van der Mei HC, Reid G. Purification and characterization of a surface-binding protein from lactobacillus fermentum RC-14 that inhibits adhesion of Enterococcus faecalis 1131. FEMS Microbiol Lett 2000;190 Suppl 1:177-80.

22. Gupta P, Diwan B. Bacterial exopolysaccharide mediated heavy metal removal: a review on biosynthesis, mechanism and remediation strategies. Biotechnol Rep Amst 2017;13:58-71.

23. Garza MTG, Perez DB, Rodriguez AV, Garcia-Gutierrez DI, Zarate X, Cardenas MEC, et al. Metal-induced production of a novel bioadsorbent exopolysaccharide in a native Rhodotorula mucilaginosa from the mexican Northeastern region. Plos One 2016;11 Suppl 2:515-22.

24. Iyer A, Mody K, Jha B. Accumulation of hexavalent chromium by an exopolysaccharide producing marine Enterobacter cloacae. Mar Pollut Bull 2004;49:974-7.

25. Pal A, Paul AK. Microbial extracellular polymeric substances: central elements in heavy metal bioremediation. Indian J Microbiol 2008;48:49.

26. Alluri HK, Ronda SR, Settalluri VS, Bondili JS, Suryanarayana V, Venkateshwar P. Biosorption: an eco-friendly alternative for heavy metal removal. Afr J Biotechnol 2007;6 Suppl 2007:2924-31.

27. Rajendran P, Muthukrishnan J, Gunasekaran P. Microbes in heavy metal remediation. Indian J Exp Biol 2003;41 Suppl 2003:935-44.

28. Bramhachari PV, Dubey SK. Isolation and characterization of the exopolysaccharide produced by Vibrio harveyi strain VB23. Lett Appl Microbiol 2006;43:571-7.

29. Zhang Z, Cai R, Zhang W, Fu Y, Jiao N. A novel exopolysaccharide with metal adsorption capacity produced by a marine bacterium Alteromonas sp. JL2810. Mar Drugs 2017; $15: 175$

30. Guibaud G, Comte S, Bordas F, Dupuy S, Baudu M. Comparison of the complexation potential of extracellular polymeric substances (EPS), extracted from activated sludges and produced by pure bacterial strains, for cadmium. Lead Nickel Chemosphere 2005;59:629-38.

31. Perez JAM, Garcia-Ribera R, Quesada T, Aguilera M, RamosCormenzana A, Mercedes M. Biosorption of heavy metals by the exopolysaccharide produced by Paenibacillusjamilae. World J Microbiol Biotechnol 2008;24:2699-704.

32. Ismail AM, Azemin WNAW, Rani A, Shamsir MS. Purification and characterization of extracellular polymeric substances (EPS) with antimicrobial properties from $\mathrm{s}$ marine epibiotic Pseudoalteromonas sp. J Teknologi Sci Eng 2012;59 Suppl 1:57-61. 